\title{
More Insight on Structure of New Binary Cerium Borate Glasses
}

\author{
Gomaa El-Damrawi1, Fawzeya Gharghar1, Rawya Ramadan² \\ ${ }^{1}$ Glass Research Group, Physics Department, Faculty of Science, Mansoura University, Mansoura, Egypt \\ ${ }^{2}$ Microwave and Dielectric Department, Physics Division, National Research Centre, Giza, Egypt \\ Email: gomaaeldamrawi@gmail.com
}

How to cite this paper: El-Damrawi, G. Gharghar, F. and Ramadan, R. (2018) More Insight on Structure of New Binary Cerium Borate Glasses. New Journal of Glass and Ceramics, 8, 12-21.

https://doi.org/10.4236/njgc.2018.81002

Received: December 7, 2017

Accepted: January 26, 2018

Published: January 29, 2018

Copyright () 2018 by authors and Scientific Research Publishing Inc. This work is licensed under the Creative Commons Attribution-NonCommercial International License (CC BY-NC 4.0). http://creativecommons.org/licenses/by-nc/4.0/ (c) (7) \& Open Access

\begin{abstract}
The structure of glasses in the system of $\mathrm{xCeO}_{2}(100-\mathrm{x}) \mathrm{B}_{2} \mathrm{O}_{3}, \mathrm{x}=30,40,50$ $\mathrm{mol} \% \mathrm{CeO}_{2}$ has been explored for the first time by correlation between data obtained from XRD, FTIR and ${ }^{11} \mathrm{~B}$ NMR analyses. NMR spectroscopy and FTIR spectroscopy have confirmed that transformation rate of $\mathrm{BO}_{3}$ to $\mathrm{BO}_{4}$ groups is reduced by $\mathrm{CeO}_{2}$ addition. The concentration of $\mathrm{Ce}_{4}-\mathrm{O}-\mathrm{Ce}_{4}$ is increased at the expense of both $\mathrm{B}_{4}-\mathrm{O}-\mathrm{Ce}_{4}$ and $\mathrm{B}_{3}-\mathrm{O}-\mathrm{B}_{4}$ linkages. Boron atoms are mainly coordinated with $\mathrm{Ce}_{4}$ sites as second neighbors due to increasing $\mathrm{CeO}_{4}$ species with further increase of $\mathrm{CeO}_{2}$ concentration. Increasing $\mathrm{B}_{4}$ fraction is considered due to forming of $\mathrm{CeO}_{4}$ with rate higher than that of $\mathrm{BO}_{4}$ units. The change of chemical shift of ${ }^{11} \mathrm{~B}$ nuclei upon exchanging $\mathrm{B}_{2} \mathrm{O}_{3}$ with $\mathrm{CeO}_{2}$ confirms that the central boron atoms would be coordinated with tetrahedral cerium atoms as second neighbors. The X-ray diffraction of cerium rich glass is clearly indicated that the formation of crystalline phases refers to $\mathrm{CeO}_{4}, \mathrm{CeBO}_{3}$ and $\mathrm{Ce}\left(\mathrm{BO}_{2}\right)_{3}$ species.
\end{abstract}

\section{Keywords}

Borate, Cerium, Former Units, NMR Analysis

\section{Introduction}

Borate glasses have attracted a great interest [1] [2] [3] [4] due to their desirable properties such as low melting temperature, high transparency, and good thermal stability. In addition, these glasses are promising host network to incorporate high concentrations from rare earth elements such as $\mathrm{CeO}_{2}$ [5]-[12]. The great importance of cerium ions is known [13]-[19] to come from their interesting characteristics such as physical, optical, catalytic and as well as magnetic properties. Particular technological applications including gamma ray shielding, 
luminescent, scintillators and dielectric, optical and electronic device are highly related to structural role of $\mathrm{CeO}_{2}$ in glasses.

Addition of a network modifier to $\mathrm{B}_{2} \mathrm{O}_{3}$ is reported [20] [21] [22] [23] [24] to break the $\mathrm{B}-\mathrm{O}$ bonds and induce the transformation of $\mathrm{BO}_{3}$ triangles to $\mathrm{BO}_{4}$ tetrahedral units. On the other hand, $\mathrm{CeO}_{2}$ plays different role when it is added to $\mathrm{B}_{2} \mathrm{O}_{3}$ since $\mathrm{CeO}_{2}$ enters to the glass network as an intermediate oxide. The modification part of $\mathrm{CeO}_{2}$ produces the conversion from $\mathrm{BO}_{3}$ to $\mathrm{BO}_{4}$ groups while the rest of $\mathrm{CeO}_{2}$ can participate in the glass network to form $\mathrm{CeO}_{4}$ tetrahedral groups.

In this regard, few structural studies on binary cerium borate glasses have been done [5] [9] [12] [25]. Changing in cerium environment around boron central atoms explains the dominant role of cerium oxide when it enters to the glass matrix as a glass former. Cerium thus behaves more as a glass modifier in low cerium content and plays the dual role at higher $\mathrm{CeO}_{2}$ concentration.

It is aimed in the present study to determine the structural role of $\mathrm{CeO}_{2}$ in cerium rich glasses by using the advantage of NMR spectroscopy, since to our knowledge, no studies in this regard have been carried out.

\section{Experimental Details}

\subsection{Sample Preparation}

The glass samples have been prepared by the normal melting method using cerium oxide $\left(\mathrm{CeO}_{2}\right)$ and boric oxide $\left(\mathrm{H}_{3} \mathrm{BO}_{3}\right)$ as starting materials. The appropriate amount of high purity chemical compounds were well mixed together to obtain fine powder. The batch mixture was then transferred to an alumina crucible and fused in an electric furnace. The melting process was carried out at different temperatures ranging between $900^{\circ} \mathrm{C}$ and $1450^{\circ} \mathrm{C}$ depending on the glass compositions. The melt was stirred several times until a complete homogenization was obtained. Each melt was then poured on stainless steel plate and pressed by another plate to take the final shape.

\subsection{Measurement Tools}

\subsubsection{X-Ray Diffraction (XRD)}

XRD measurements were carried out on powdered samples at (Metallurgical Institute, El-Tebbeen-Helwan) using a BrukerAxs-D8 Advance powder XRD system with a $\mathrm{Cu} \mathrm{K} \alpha$ radiation $\left(\lambda_{\mathrm{CuKa}}=0.1540600 \mathrm{~nm}\right)$.

The range of the diffraction angle $(2 \theta)$ is changed from $4^{\circ}$ to $70^{\circ}$ using a dwell time of 0.4 seconds.

\subsection{2. ${ }^{11} \mathrm{~B}$ NMR Measurements}

Solid-state ${ }^{11} \mathrm{~B}$ NMR spectra were performed at Magnetic Resonance unit, Mansura University. The samples were measured with JEOL GSX-500 high-resolution solid-state MAS NMR spectrometer in a magnetic field of $11.74 \mathrm{~T}$ at ${ }^{11} \mathrm{~B}$ Larmor frequency of $160.4 \mathrm{MHz}$ and spinning rate of $15 \mathrm{KHz}$. A single pulse length was 
used of 0.5 - $1.0 \mathrm{~ms}$ with a pulse delay of $2.5 \mathrm{~s}$, and an accumulation of 200 -300 scans. All Samples were grinded to fine powders then filled into standard 4 mm NMR sample tubes.

\subsubsection{Fourier Transform Infrared Spectra (FTIR)}

FTIR Spectra of powdered glasses were obtained in the wavenumber range of 400 to $4000 \mathrm{~cm}^{-1}$ using a Fourier transform IR spectrometer (Mattson 5000, Fine Measurements Laboratory, Mansura University, Egypt) with a resolution of $2 \mathrm{~cm}^{-1}$. Each sample was mixed with $\mathrm{KBr}$ by the ratio 1:100 in weight and then subjected to a pressure of load of 5 tons $/ \mathrm{cm}^{2}$ to produce a homogeneous pellet. The infrared absorbance measurements were carried out at room temperature immediately after preparing.

The spectra were corrected for the background and the dark current noises using two points baseline corrections then were normalized by making the absorption of every spectrum varying from zero to one reported in arbitrary units.

\section{Results and Discussion}

\subsection{X-Ray Analysis}

Figure 1 presents XRD diffraction patterns for $\mathrm{xCeO}_{2}(100-\mathrm{x}) \mathrm{B}_{2} \mathrm{O}_{3}$ with $\mathrm{x}=30$, 40, $50 \mathrm{~mol} \% \mathrm{CeO}_{2}$. The compositions of 30 and $40 \mathrm{~mol} \% \mathrm{CeO}_{2}$ were mainly amorphous, whereas composition containing $50 \mathrm{~mol} \% \mathrm{CeO}_{2}$ was partially crystallized. As it can be a notable, the amorphous structure of the glass network

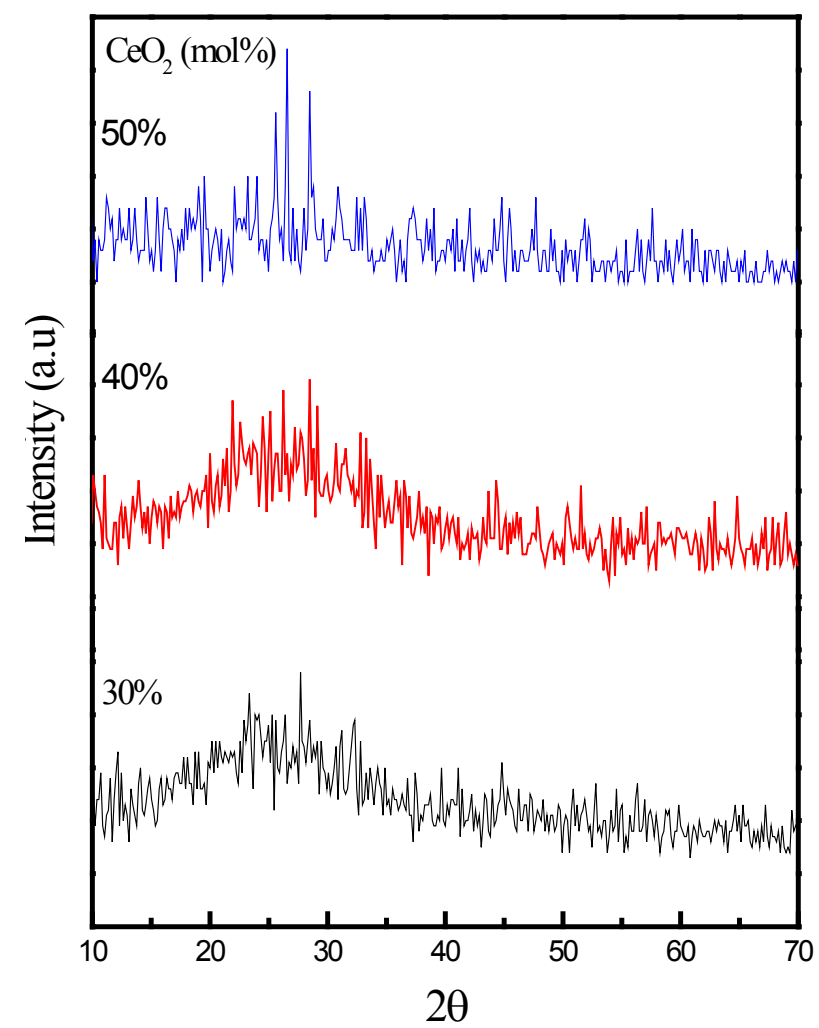

Figure 1. XRD patterns of binary cerium borate a function of $\mathrm{CeO}_{2}$ concentration. 
containing 30 and $40 \mathrm{~mol} \% \mathrm{CeO}_{2}$ is clearly evidenced, since a broad hump characterizing this feature is indicated in the XRD spectra of the glasses. On the other hand, sharper XRD peaks are developed on the spectra of glass contains 50 $\mathrm{mol} \% \mathrm{CeO}_{2}$. The discrete sharp lines observed at $\sim 25.7,28.6,30.8,37.6,47.49^{\circ}$ are mainly assigned to crystalline $\mathrm{CeO}_{4}$ [PDF nr.810792], $\mathrm{CeBO}_{3}$ [PDF nr.210177] and $\mathrm{Ce}\left(\mathrm{BO}_{2}\right)_{3}[\mathrm{PDFnr}$.230877] species. The strong tendency to crystallization may attributed to increasing in network connectivity as result of further concentration of tetrahedral $\mathrm{CeO}_{4}$ as former species [9] [10] [12]. The tetrahedral $\mathrm{CeO}_{4}$ groups have the priority to combine together with $\mathrm{B}$ atoms and form an ordered structural chain in Ce-O-B linkages causing an increment in crystallization.

These considerations are further supported through comparison between XRD pattern of pure $\mathrm{CeO}_{2}$ as shown in Figure 2 and that of cerium borate glass containing $50 \mathrm{~mol} \% \mathrm{CeO}_{2}$. Both spectra offer sharp diffraction lines ranged between $25^{\circ}$ and $35^{\circ}$. On other hand, the intensities of diffraction patterns of cerium borate glass are appeared to be lower than that of pure $\mathrm{CeO}_{2}$. In such a case, the distribution of the accumulated $\mathrm{CeO}_{4}$ units within the amorphous borate structure units may play the role of lowering the crystallinty.

\section{2. ${ }^{11 B ~ N M R ~ S p e c t r o s c o p y ~}$}

${ }^{11} \mathrm{~B}$ NMR spectra of alkali modified borate glasses were generally possessed two well separated peaks [10] [26] [27] [28] [29]. One is corresponding to $\mathrm{BO}_{3}$ and the other is related to $\mathrm{BO}_{4}$ sites. The broad ${ }^{11} \mathrm{~B}$ NMR resonance with peak centered at about $\sim 12 \mathrm{ppm}$ is assigned to different trigonal boron species distributed as boroxol and non-ring $\mathrm{BO}_{3}$ units. While the more intensive and sharper peak located around $0 \mathrm{ppm}$ is due to resonance of four-coordinate boron species.

It worthy to note that features of ${ }^{11} \mathrm{BNMR}$ spectra of cerium borate glasses [10] are quite different from that of-alkali and alkaline earth binary borate

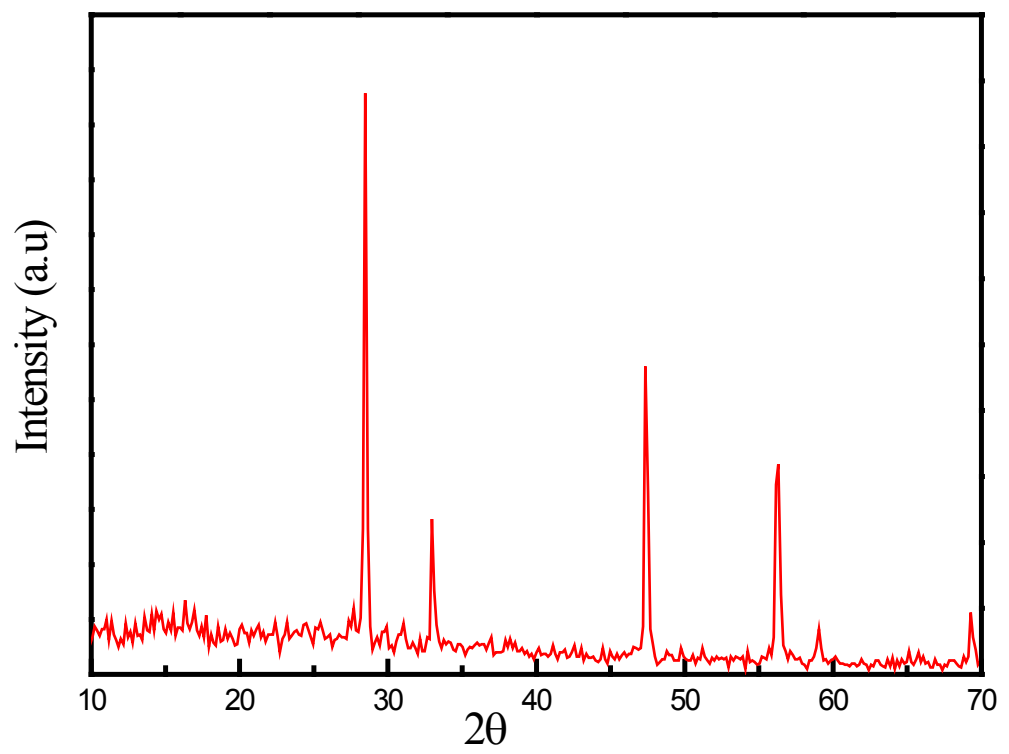

Figure 2. XRD patterns of pure $\mathrm{CeO}_{2}$. 
glasses. In glasses modified by $\mathrm{CeO}_{2}$, the $\mathrm{BO}_{4}$ and $\mathrm{BO}_{3}$ peaks are being broader and totally overlapped, as presented in Figure 3. This was especially true for the glass containing $40 \mathrm{~mol} \% \mathrm{CeO}_{2}$ which displayed asymmetrically broadened peak. The more pronounce broadening leads one to strongly suggest that presence of a $\mathrm{BO}_{4}$ site with $2 \mathrm{BO}_{3}$ and $2 \mathrm{CeO}_{4}$ in next nearest neighbor environments. The difference in bond length and bond angle between $\mathrm{B}_{3}-\mathrm{O}-\mathrm{Ce}_{4}$ and $\mathrm{Ce}_{4}-\mathrm{O}-\mathrm{B}_{4}$ linkages is considered as the main reason for spectral broadening in glass containing 40 $\mathrm{mol} \% \mathrm{CeO}_{2}$. On the other hand, glass containing $50 \mathrm{~mol} \% \mathrm{CeO}_{2}$ showed more symmetric and less broadening behavior than that of glass containing $40 \mathrm{~mol} \%$ $\mathrm{CeO}_{2}$. This can be discussed on the bases of presence a $\mathrm{BO}_{4}$ site coordinated with more $\mathrm{CeO}_{4}$ units in next nearest neighbor environment. In this regard, $\mathrm{BO}_{4}$ site with three or four $\mathrm{CeO}_{4}$ sites may efficiently be formed. Enhancement of $\mathrm{CeO}_{4}$ species around central $\mathrm{B}$ atom will result in increasing the symmetry elements in the whole glass network, since the majority of bonds are of $\mathrm{Ce}_{4}-\mathrm{O}-\mathrm{Ce}_{4}$ type and limited bonds are formed with borate units. The symmetric of bonds around boron units will consequently change the value of chemical shift to become nearer to $\mathrm{BO}_{4}$ surrounding with $4 \mathrm{BO}_{3}$, since the observed chemical shift is appeared around $0 \mathrm{ppm}$. In such a case, we can suggest that, chemical shielding of $\mathrm{BO}_{4}$ coordinated with $4 \mathrm{BO}_{3}$ is similar to $\mathrm{BO}_{4}$ coordinated with $4 \mathrm{CeO}_{4}$, since both possess the same value of chemical shift.

As shown in Figure 3, the lower value of $\mathrm{CeO}_{2}(30 \mathrm{~mol} \%)$ will affect the spectral feature, since two distinguished peaks are resolved. One characterizing $\mathrm{BO}_{3}$ units and the other can be argued to be due to $\mathrm{BO}_{4}$ site with $3 \mathrm{BO}_{3}$ and one $\mathrm{CeO}_{4}$ sites. Presence of $\mathrm{CeO}_{4}$ with lower site around $\mathrm{BO}_{4}$ results in changing the

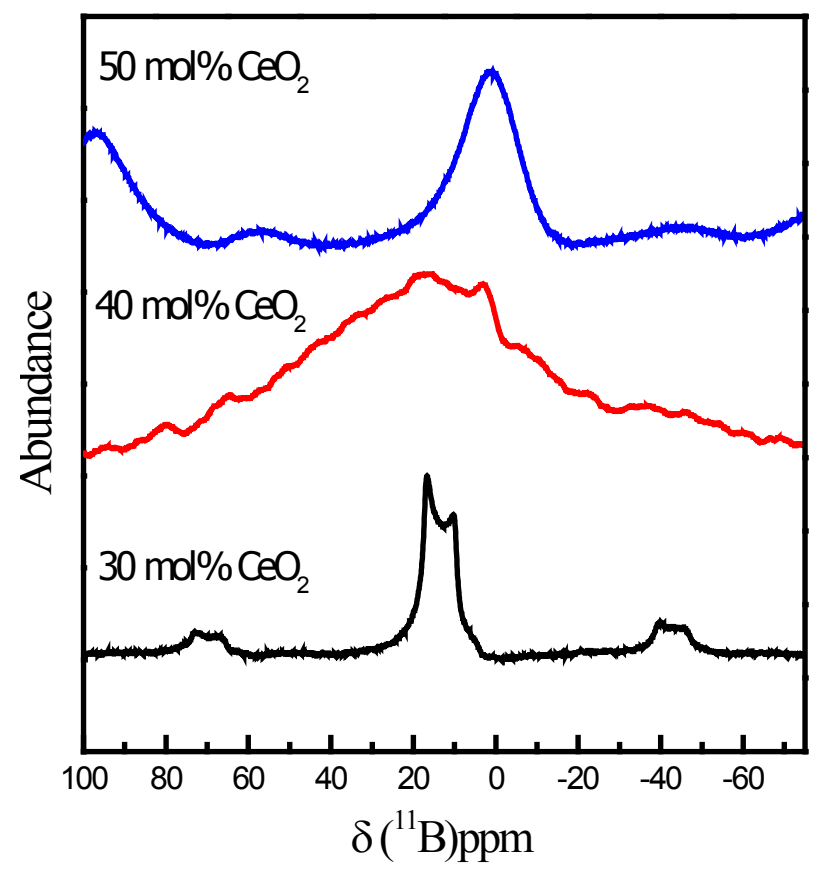

Figure 3. ${ }^{11} \mathrm{~B}$ NMR spectra of binary cerium borate glasses as function of $\mathrm{CeO}_{2}$ concentration. 
position of spectral peak to more positive value since shielding of $\mathrm{BO}_{4}$ atoms from $\mathrm{BO}_{3}$ sites differs from that with $\mathrm{CeO}_{4}$. Thus, chemical shifts of the studied system have obviously been varied from 12 ppm for glass containing $30 \mathrm{~mol} \%$ $\mathrm{CeO}_{2}$ to 0 ppm in glass enriched with $\mathrm{CeO}_{2}$.

\subsection{FTIR Analysis}

FT-IR spectra of samples with $\mathrm{x}=30,40,50 \mathrm{~mol} \% \mathrm{CeO}_{2}$ are displayed in Figure 4. Three fundamental absorption bands [23] [30] [31] [32] have been observed in the borate glass system. The first band located between $600-800 \mathrm{~cm}^{-1}$ is assigned to symmetric bending vibrations of $\mathrm{BO}_{3}$ bonds. The second band from $800-1200 \mathrm{~cm}^{-1}$ can be attributed to $\mathrm{BO}_{4}$ stretching vibrations, while the third band from $1200-1600 \mathrm{~cm}^{-1}$ is assigned to $\mathrm{B}-\mathrm{O}$ stretching vibrations of triangular $\mathrm{BO}_{3}$ units.

As noted from Figure 4, structural changes appeared in a wide and asymmetric broadening, with increasing $\mathrm{CeO}_{2}$ content. Particularly, these changes are notable in the intensity of band ranged between 800 to $1200 \mathrm{~cm}^{-1}$. Such tendency is possible to the main role played by $\mathrm{CeO}_{2}$ through presenting more $\mathrm{CeO}_{4}$ units in the glass structure and their abilities to shield and coordinate with $\mathrm{BO}_{4}$ units. As a consequence, increasing of $\mathrm{CeO}_{2}$ at the expense of $\mathrm{B}_{2} \mathrm{O}_{3}$ results in increasing of $\mathrm{Ce}_{4}-\mathrm{O}-\mathrm{Ce}_{4}$ bonds at expense of $\mathrm{B}_{4}-\mathrm{O}-\mathrm{B}_{3}$. In such a case, the glass structure is mainly consisting of $\mathrm{Ce}_{4}-\mathrm{O}$ bond in $\mathrm{CeO}_{4}$ groups. Moreover, formation of some mixed vibrations from $\mathrm{Ce}_{4}-\mathrm{O}$ with $\mathrm{B}_{4}-\mathrm{O}$ and $\mathrm{B}_{3}-\mathrm{O}$ may also be suggested. The results of these measurements are quite in good agreement with those obtained from NMR of the same glasses.

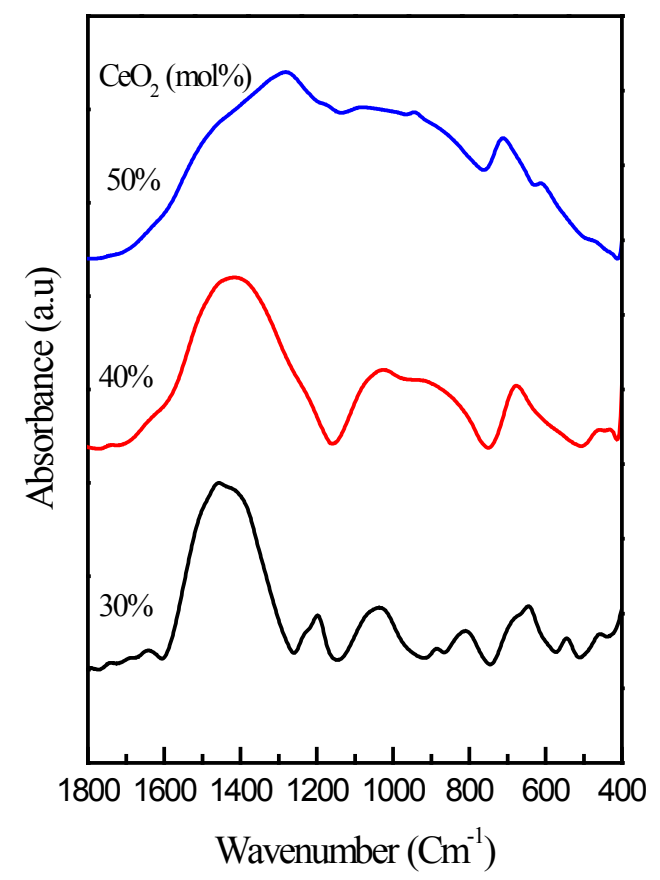

Figure 4. FTIR absorbance spectra of binary cerium borate glasses a function of $\mathrm{CeO}_{2}$ concentration. 
The total fraction of four-coordinated units, $\mathrm{B}_{4}$, could be calculated for the three samples using a deconvolution procedure [5] [25] [31] [32]. This can be done by obtaining the relative area of each band corresponding to the structural units of both triangular $\mathrm{BO}_{3}$ and tetrahedral $\mathrm{BO}_{4} \& \mathrm{CeO}_{4}$ units.

As a result, the value of $\mathrm{B}_{4}$ is then defined as the ratio of the area related to the sum of structural groups containing $\mathrm{BO}_{4}$ and $\mathrm{CeO}_{4}$ four coordinated units to the area related to total units $\left(\mathrm{BO}_{3}+\mathrm{BO}_{4}+\mathrm{CeO}_{4}\right)$. Figure 5 represents an example for the deconvolution in Gaussian band of $50 \mathrm{CeO}_{2} \cdot 50 \mathrm{~B}_{2} \mathrm{O}_{3}$ glass sample.

Figure 6 illustrates the change in the total fraction $\mathrm{B}_{4}$ versus $\mathrm{CeO}_{2}$ content of

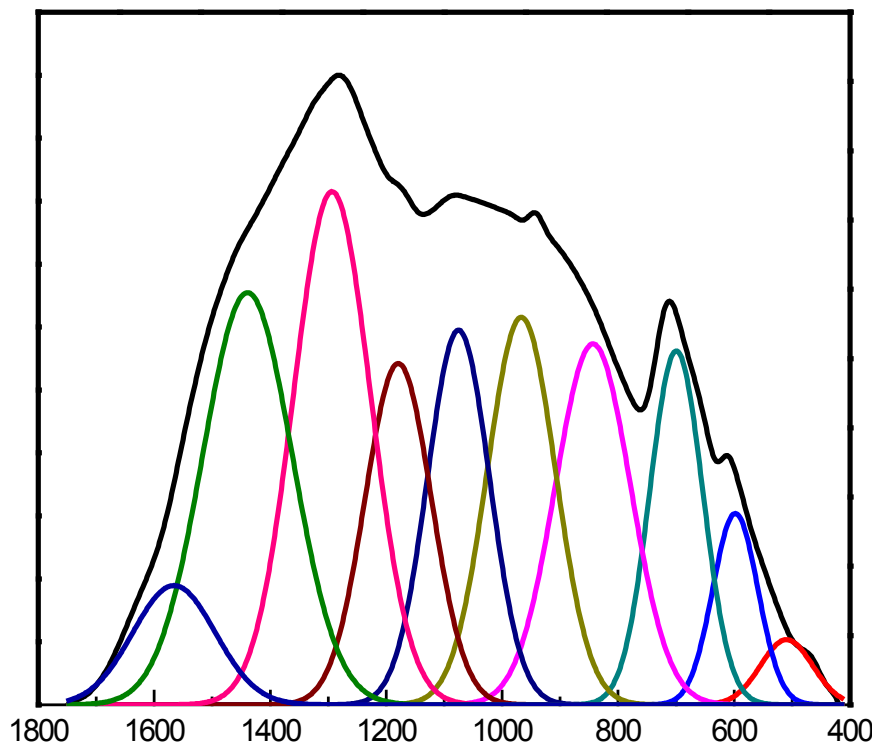

Figure 5. Deconvolution of infrared spectrum of the composition $50 \mathrm{CeO}_{2} \cdot 50 \mathrm{~B}_{2} \mathrm{O}_{3}$ as an example for the analysis.

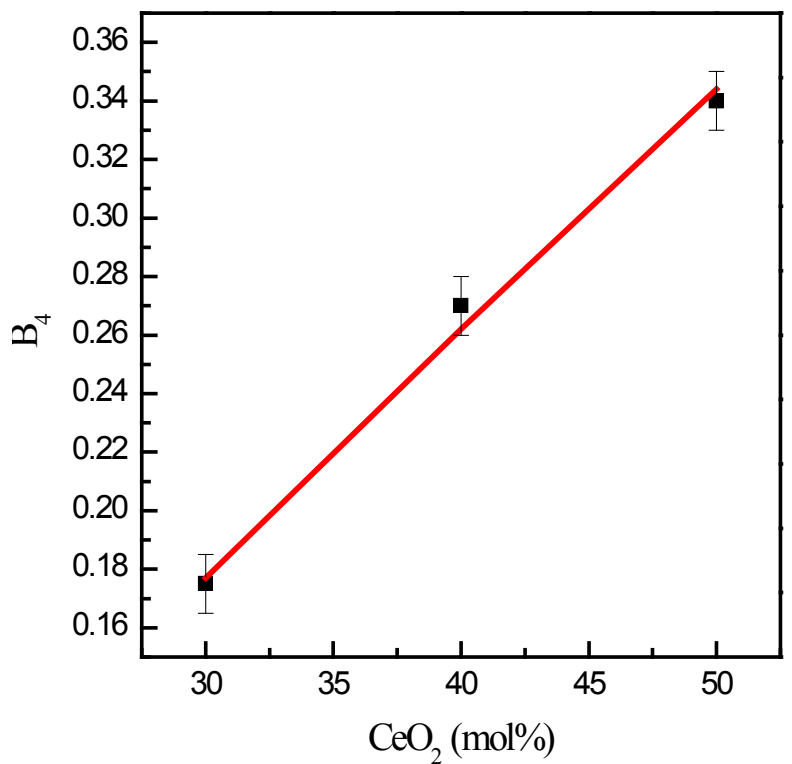

Figure 6. $\mathrm{B}_{4}$ fraction of binary cerium borate glasses as function of $\mathrm{CeO}_{2}$ concentration. 
the studied glass samples. It can be observed from this figure, there is a linear dependence between $\mathrm{B}_{4}$ and the change of $\mathrm{CeO}_{2}$ composition. The role of $\mathrm{CeO}_{2}$ in increasing $\mathrm{B}_{4}$ may be attributed to the considerable frequent increasing in tetrahedral units in glass network at expense of $\mathrm{BO}_{3}$ units. This reveals that the former role of cerium may become more dominant in glass riches with cerium oxide (50 mol\%). In such a case, the linkage between $\mathrm{CeO}_{4}$ and both $\mathrm{BO}_{3}$ and $\mathrm{BO}_{4}$ groups is being the most abundant within glass network. Such argument becomes clearly visible from FTIR spectra, particularly in glass of $50 \mathrm{~mol} \% \mathrm{CeO}_{2}$, where the shoulder at about $1600 \mathrm{~cm}^{-1}$ is assigned to Ce-O vibration in phase rich with cerium borate mixed units.

\section{Conclusions}

The structural features of cerium borate glasses correlated with $\mathrm{CeO}_{2}$ role have been investigated via different tools. The following conclusions can summarize the observed new features.

- XRD results revealed that, crystallization would take place in glasses with 50 mol\% $\mathrm{CeO}_{2}$. In such a glass, the principal crystalline phase is assigned to crystalline $\mathrm{CeO}_{4}, \mathrm{CeBO}_{3}$ and $\mathrm{Ce}\left(\mathrm{BO}_{2}\right)_{3}$ species which is mainly referred to both $\mathrm{CeO}_{4}$ and $\mathrm{BO}_{4}$ as dominated units.

- FTIR spectroscopy and NMR spectroscopy have confirmed that $\mathrm{CeO}_{2}$ in binary borate glasses plays mainly the role of glass former in the form of $\mathrm{CeO}_{4}$ units. The formation of expected ordered $\mathrm{Ce}_{4}-\mathrm{B}_{-}-\mathrm{Ce}_{4}$ linkage impairs the conversion of triangular $\mathrm{BO}_{3}$ units into $\mathrm{BO}_{4}$ tetrahedra and causes a wide broadening in the spectrum.

- Increasing of the total fraction of all four coordinated units $\left(\mathrm{B}_{4}\right)$ is highly associated with increasing in $\mathrm{CeO}_{4}$ concentration and this would consequently result in formation of more ordered structures.

- The change in chemical shifts of ${ }^{11} \mathrm{~B}$ nuclei from $12 \mathrm{ppm}$ to $0 \mathrm{ppm}$ with increasing $\mathrm{CeO}_{2}$ content from 30 to $50 \mathrm{~mol} \%$ is considered due to formation of more shielded borate units via B-O-Ce bonds. Each born atom can be coordinated with 3 or $4 \mathrm{Ce}$ atoms in the second coordination sphere.

\section{References}

[1] Pye, L., Fréchette, V. and Kreidl, N. (2012) Borate Glasses: Structure, Properties, Applications. Volume 12, Springer Science \& Business Media, Part of the Materials Science Research Book Series, MSR.

[2] Bengisu, M. (2016) Borate Glasses for Scientific and Industrial Applications: A Review. Journal of Materials Science, 51, 2199-2242.

[3] Oprea, I. (2005) Optical Properties of Borate Glass-Ceramics. PhD Diss., Osnabruck University, Germany.

[4] Minakova, N., Zaichuk, A. and Belyi, Y. (2008) The Structure of Borate Glass. Glass and Ceramics, 65, 70-73.

[5] El-Damrawi, G. and El-Egili, K. (2001) Characterization of Novel $\mathrm{CeO}_{2}-\mathrm{B}_{2} \mathrm{O}_{3}$ Glasses, Structure and Properties. Physica B, Condensed Matter, 299, 180-186. 
[6] Singh, G., Kaur, P., Kaur, S. and Singh, D. (2012) Investigation of Structural, Physical and Optical Properties of $\mathrm{CeO}_{2}-\mathrm{Bi}_{2} \mathrm{O}_{3}-\mathrm{B}_{2} \mathrm{O}_{3}$ Glasses. Physica B: Condensed Matter, 407, 4168-4172.

[7] Kelly, T., Petrosky, J., McClory, J., Adamiv, V., Burak, Y., Padlyak, B., Teslyuk, I., Lu, N., Wang, L., Mei, W. and Dowben, P. (2014) Rare Earth Dopant (Nd, Gd, Dy, and Er) Hybridization in Lithium Tetraborate. Frontiers in Physics, 2, 31.

[8] Pisarski, W., Pisarska, J., Lisiecki, R., Dominiak-Dzik, G. and Ryba-Romanowski, W. (2010) Laser Spectroscopy of Rare Earth Ions in Lead Borate Glasses and Transparent Glass-Ceramics. Laser Physics, 20, 649-655.

[9] Mansour, E., El-Egili, K. and El-Damrawi, G. (2007) Mechanism of Hopping Conduction in $\mathrm{New} \mathrm{CeO}_{2}-\mathrm{B}_{2} \mathrm{O}_{3}$ Semiconducting Glasses. Physica B: Condensed Matter, 389, 355-361.

[10] El-Damrawi, G., Gharghar, F., Ramadan, R. and Aboelez, M. (2016) ${ }^{11}$ B NMR Spectroscopy of Lead Borate Glasses: Additive Effect of Cerium Oxide. New Journal of Glass and Ceramics, 6, 57.

[11] Trégouët, H., Caurant, D., Majérus, O., Charpentier, T., Cormier, L. and Pytalev, D. (2014) Spectroscopic Investigation and Crystallization Study of Rare Earth Metaborate Glasses. Procedia Materials Science, 7, 131-137.

https://doi.org/10.1016/j.mspro.2014.10.018

[12] Mansour, E., El-Egili, K. and El-Damrawi, G. (2007) Ionic-Polaronic Behavior in $\mathrm{CeO}_{2}-\mathrm{PbO}-\mathrm{B}_{2} \mathrm{O}_{3}$ Glasses. Physica B: Condensed Matter, 392, 221-228.

https://doi.org/10.1016/j.physb.2006.11.022

[13] Liu, H., Huang, J., Zhao, D., Yang, H. and Zhang, T. (2016) Improving the Electrical Property of $\mathrm{CeO}_{2}$-Containing Sealing Glass-Ceramics for Solid Oxide Fuel Cell Applications: Effect of $\mathrm{HfO}_{2}$. Journal of the European Ceramic Society, 36, 917-923. https://doi.org/10.1016/j.jeurceramsoc.2015.10.004

[14] Zu, C., Chen, J., Zhao, H., Han, B., Liu, Y. and Wang, Y. (2009) Effect of Cerium on Luminescence and Irradiation Resistance of $\mathrm{Tb}^{3+}$ Doped Silicate Glasses. Journal of Alloys and Compounds, 479, 294-298. https://doi.org/10.1016/j.jallcom.2008.12.037

[15] Girija, D., Naik, H., Sudhamani, C. and Kumar, B. (2011) Cerium Oxide Nanoparticles-A Green, Reusable, and Highly Efficient Heterogeneous Catalyst for the Synthesis of Polyhydroquinolines under Solvent-Free Conditions. Archives of Applied Science Research, 3, 373-382.

[16] Culea, E., Neumann, M., Takacs, A., Pop, L., Culea, M., Bosca, M. and Marcean, R. (2005) Structural and Magnetic Behavior of Some Oxide Glasses Containing Cerium Ions. Annals of the West University of Timisoara, Physics Series, 46, 117-120.

[17] Deshpande, V. and Taikar, R. (2010) Effect of Cerium Oxide Addition on Electrical and Physical Properties of Alkali Borosilicate Glasses. Materials Science and Engineering, 172, 6-8. https://doi.org/10.1016/j.mseb.2010.04.003

[18] Jha, A. (2014) Rare Earth Materials: Properties and Applications. CRC Press, Boca Raton. https://doi.org/10.1201/b17045

[19] Kielty, M. (2016) Cerium Doped Glasses: Search for a New Scintillator. PhD, Clemson University, Clemson.

[20] Mansour, E., Doweidar, H., El-Damrawi, G. and Moustafa, Y. (2004) Mixed Alkali Effect in Polaronic Conducting Iron Borate Glasses. Journal of Materials Science, 39, 4325-4329. https://doi.org/10.1023/B:JMSC.0000033418.94760.70

[21] Doweidar, H., Moustafa, Y., Abd El-Maksoud, S. and Silim, H. (2001) Properties of $\mathrm{Na}_{2} \mathrm{O}-\mathrm{Al}_{2} \mathrm{O}_{3}-\mathrm{B}_{2} \mathrm{O}_{3}$ Glasses. Materials Science and Engineering, 301, 207-212. 
https://doi.org/10.1016/S0921-5093(00)01786-X

[22] Doweidar, H., El-Damrawi, G. and Al-Zaibani, M. (2013) Distribution of Species in $\mathrm{Na}_{2} \mathrm{O}-\mathrm{CaO}-\mathrm{B}_{2} \mathrm{O}_{3}$ Glasses as Probed by FTIR. Vibrational Spectroscopy, 68, 91-95. https://doi.org/10.1016/j.vibspec.2013.05.015

[23] Gautam, C., Yadav, A. and Singh, A. (2012) A Review on Infrared Spectroscopy of Borate Glasses with Effects of Different Additives.

[24] Othman, H., Elkholy, H. and Hager, I. (2016) FTIR of Binary Lead Borate Glass: Structural Investigation. Journal of Molecular Structure, 1106, 286-290. https://doi.org/10.1016/j.molstruc.2015.10.076

[25] El-Damrawi, G., Gharghar, F. and Ramadan, R. (2016) Structural Studies on New $\mathrm{xCeO}_{2} \cdot(50-\mathrm{x}) \mathrm{PbO} \cdot 50 \mathrm{~B}_{2} \mathrm{O}_{3}$ Glasses and Glass Ceramics. Journal of Non-Crystalline Solid, 452, 291-296. https://doi.org/10.1016/j.jnoncrysol.2016.09.011

[26] Zhou, B., Sun, Z., Yao, Y. and Pan, Y. (2012) Correlations between ${ }^{11}$ B NMR Parameters and Structural Characters in Borate and Borosilicate Minerals Investigated by High-Resolution MAS NMR and ab initio Calculations. Physics and Chemistry of Minerals, 39, 363-372. https://doi.org/10.1007/s00269-012-0482-3

[27] Michaelis, V., Aguiar, P. and Kroeker, S. (2007) Probing Alkali Coordination Environments in Alkali Borate Glasses by Multinuclear Magnetic Resonance. Journal of Non-Crystalline Solids, 353, 2582-2590.

https://doi.org/10.1016/j.jnoncrysol.2007.04.029

[28] Clarida, W., Berryman, J., Affatigato, M., Feller, S., Kroeker, S., Zwanziger, W., Meyer, B., Borsa, F. and Martin, S. (2003) Dependence of $\mathrm{N}_{4}$ upon Alkali Modifier in Binary Borate Glasses. Physics and Chemistry of Glasses, 44, 215-217.

[29] Takaishi, T., Jin, J., Uchino, T. and Yoko, T. (2000) Structural Study of $\mathrm{PbO}-\mathrm{B}_{2} \mathrm{O}_{3}$ Glasses by X-Ray Diffraction and ${ }^{11} \mathrm{~B}$ MAS NMR Techniques. Journal of the American Ceramic Society, 83, 2543-2548. https://doi.org/10.1111/j.1151-2916.2000.tb01588.x

[30] Ibrahim, S., Gomaa, M. and Darwish, H.H. (2014) Influence of $\mathrm{Fe}_{2} \mathrm{O}_{3}$ on the Physical, Structural and Electrical Properties of Sodium Lead Borate Glasses. Journal of Advanced Ceramics, 3, 155-164. https://doi.org/10.1007/s40145-014-0107-z

[31] Verhoef, A. and Den Hartog, H. (1995) Infrared Spectroscopy of Network and Cation Dynamics in Binary and Mixed Alkali Borate Glasses. Journal of Non-Crystalline Solids, 182, 221-234. https://doi.org/10.1016/0022-3093(94)00555-9

[32] Kamitsos, E., Patsis, A., Karakassides, M. and Chryssikos, G. (1990) Infrared Reflectance Spectra of Lithium Borate Glasses. Journal of Non-Crystalline Solids, 126, 52-67. https://doi.org/10.1016/0022-3093(90)91023-K 